\title{
The Impact of Trade Facilitation on Cross-Border E-Commerce Transactions: Analysis Based on the Marine and Land Cross-Border Logistical Practices between China and Countries along the "Belt and Road"
}

\author{
Yingying Liang ${ }^{1}$, Liangliang Guo ${ }^{1}$, Jianlu Li ${ }^{2, *}$, Shuang Zhang ${ }^{1}$ and Xiangyun Fei ${ }^{1}$ \\ 1 School of Economics and Management, Liaoning University of Technology, No. 169, Shi Ying Street, \\ Guta District, Jinzhou 121000, China; lnliangyingying@163.com (Y.L.); 15538087419@163.com (L.G.); \\ shuangcheung@126.com (S.Z.); fxy1241563176@163.com (X.F.) \\ 2 College of Business Administration Maharishi International University (MIU), 1000 N. 4th Street, \\ Fairfield, IA 52557, USA \\ * Correspondence: hgxy544266@163.com; Tel.: +86-18004067107
}

\section{check for}

updates

Citation: Liang, Y.; Guo, L.; Li, J.; Zhang, S.; Fei, X. The Impact of Trade Facilitation on Cross-Border E-Commerce Transactions: Analysis Based on the Marine and Land Cross-Border Logistical Practices between China and Countries along the "Belt and Road". Water 2021, 13, 3567. https://doi.org/10.3390/ w13243567

Academic Editor: Shuhong Wang

Received: 29 October 2021

Accepted: 6 December 2021

Published: 13 December 2021

Publisher's Note: MDPI stays neutral with regard to jurisdictional claims in published maps and institutional affiliations.

Copyright: (c) 2021 by the authors. Licensee MDPI, Basel, Switzerland. This article is an open access article distributed under the terms and conditions of the Creative Commons Attribution (CC BY) license (https:/ / creativecommons.org/licenses/by/ $4.0 /)$.

\begin{abstract}
In the post-epidemic era, cross-border e-commerce has become a new growth point for global foreign trade. Unlike traditional trade, which is dominated by marine transport, cross-border e-commerce transactions have high requirements for both marine and land transport, and the scale of their trade is accordingly limited by the level of trade facilitation i.e., the convenience of crossborder logistics in bilateral trading countries. Based on transaction cost theory, this article takes cross-border e-commerce transactions between China and countries along "The Belt and Road" as the core of the study. From the perspective of marine and land transport timeliness, the theoretical framework is constructed using the marine and land logistics infrastructure, customs clearance environment, government-governance environment, and cross-border logistics services as the main influencing paths; the GMM method is then applied in order to conduct a study on the impact of trade facilitation on the scale effect of cross-border e-commerce. The study finds that marine and land transport infrastructure has the strongest impact, with customs clearance environment and government-governance environment having the second strongest and comparable impact. The findings of the study further clarify the differences in the application of different cross-border logistics facilitation measures, and provide a theoretical basis for improving the timeliness of cross-border e-commerce transactions and reducing trade costs as well as a reference for the realization of land-sea integration and land-sea interconnection under "The Belt and Road" initiative.
\end{abstract}

Keywords: cross-border logistics facilitation; marine transport; cross-border e-commerce; China railway express; SYS-GMM estimation

\section{Introduction}

The current global multi-billion-level consumer market tends to be e-commerce. At the same time, "The Belt and Road" initiative put forward by the Chinese government has deepened the integration of countries along the route with China's ocean economy, and has promoted cross-border e-commerce to become a new driving force for global trade growth. In traditional goods trade, marine transportation is the mainstream mode of transportation due to large transaction volumes. However, marine transportation is easily affected and restricted by natural conditions such as waterway hydrological conditions and meteorological conditions. In cross-border e-commerce, due to the small transaction volume of a single order and the higher requirements of the consignee on with respect to the timeliness of transportation, marine-land transportation is the mainstay for ensuring that goods can be delivered to customers on time. To this end, some companies rely on border ports and cross-border logistics channels to set up border warehouses, or set 
up overseas warehouses in destination countries to better meet customer consumption experience. Because overseas warehouses are restricted by the political environment of a country's market, their establishment is not suitable for all countries along the "Belt and Road". Correspondingly, the development of cross-border e-commerce transactions will also be affected and restricted by a country's trade facilitation environment. In the past eight years, China's cross-border e-commerce transaction scale has reached RMB 12.5 trillion, an increase of $11.6 \%$ year-on-year, and the transaction scale accounted for $38.86 \%$ (Figure 1). Driven by the "The Belt and Road" policy, the General Administration of Customs of China has successively issued a series of trade facilitation measures which have continuously optimized the marine economic environment and effectively reduced transaction costs and expenses such as cross-border shipping and land transportation. It is particularly necessary to explore the impact mechanism of cross-border e-commerce transaction scale growth against the trend of cross-border logistics facilitation, as this is the core of the new era around the practice of marine and land cross-border logistics.

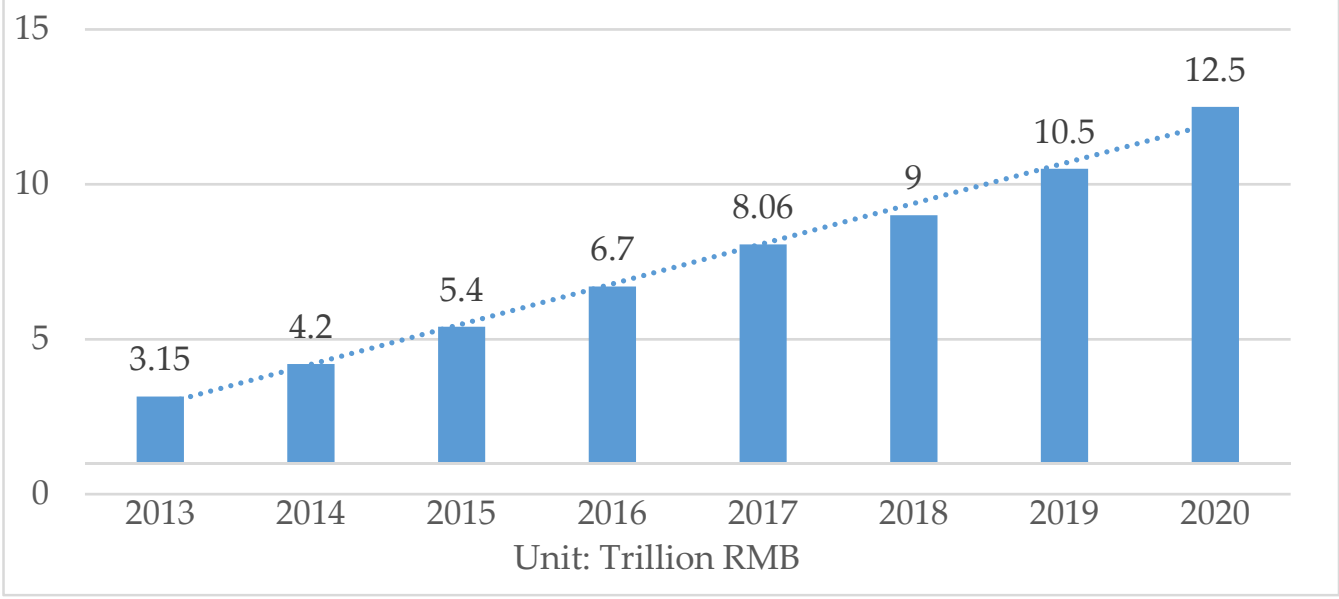

Figure 1. Cross-border e-commerce transaction scale in China, 2013-2020. Data source: China Network Economy Platform Data Center.

The essence of trade is information flow, capital flow and logistics. In terms of information flow, compared with traditional foreign trade transactions cross-border e-commerce transactions use various forms of carriers to collect, publish and exchange information through e-commerce platform websites so as to complete transaction negotiations in the most convenient way, thus realizing efficient transmission of information flow. Comparing capital flow with traditional trade settlement methods, its complexity is more focused on dealing with the remittance of different currencies of different overseas buyers and the compatibility of various types of different localized payment methods, mainly involving settlement and billing issues; however at present, cross-border payment platforms such as Stripe, PayPal, Amazon Pay, Payoneer, Alipay, etc., have realized the settlement of payment for goods on both sides. It can be seen that in terms of information flow and capital flow, cross-border e-commerce transactions can bring lower transaction costs than traditional trade. However, in terms of logistics, cross-border e-commerce transactions face bottlenecks in development similar to traditional trade transactions. Examples include cumbersome customs clearance procedures, poor infrastructure at marine logistics ports, low quality of land transport services, low efficiency of port crossings, and other cross-border logistics non-facilitation environmental issues. In view of this, the WTO promulgated and implemented the Trade Facilitation Agreement in 2017, aiming to achieve simplification and transparency of trade procedures in member countries to facilitate the free flow of goods and services.

At present, the world's economic and trade development is in a very sensitive period; unilateralism and trade protectionism are expected to rise further, leading to an increase in 
non-tariff barriers in the future and a more severe export trade situation; coupled with the secondary impact of the epidemic, this results in downward pressure on traditional trade transactions and many negative factors overlapping [1]. At this time, the flexibility and convenience of cross-border e-commerce online transactions highlight the advantages of the future may usher in a new round of opportunities and challenges. How the government, e-commerce enterprises and consumers can rely on the optimization of the trade facilitation environment to carry out cross-border e-commerce transactions is a pressing issue worthy of in-depth consideration and exploration.

In view of this, the present paper constructs a conceptual model of the impact of trade facilitation on cross-border e-commerce transactions by taking cross-border e-commerce transactions between China and the countries along the "Belt and Road" as the research object. Based on this model, we use panel data to examine the differences in the impact of trade facilitation measures on cross-border e-commerce transactions in terms of infrastructure, customs clearance environment, government-governance capacity, and cross-border logistics services on the scale of cross-border e-commerce transactions in the countries along the "Belt and Road".

\section{Literature Review}

In domestic and international academic circles, trade facilitation, cross-border e-commerce transactions, trade scale and other research themes have been fruitful areas of study in recent years; however, the results of exploring the impact of trade facilitation environment on the scale of cross-border e-commerce transactions are very limited. The existing studies, mainly along the lines of trade facilitation and the construction of its indicator system, the impact of trade facilitation on trade scale, etc., gradually deepen and unfold [2].

\subsection{Review on the Connotation and Evaluation of Trade Facilitation}

Trade facilitation connotes the enhancement and improvement of trade effects through the simplification of trade procedures and formalities, harmonization of applicable laws and regulations, and standardization and improvement of infrastructure, i.e., by preventing and controlling trade risks and reducing trade costs [3]. The OECD estimates that for every $1 \%$ reduction in trade costs, trade can increase by USD 40 billion. Regarding the measurement of trade facilitation indicators, traditional studies focus on the simplification and harmonization of international trade procedures, i.e., the reduction of trade costs that occur at the "border", mainly related to the transparency of the rules of the customs control system, customs clearance efficiency, tariff system, etc. The contemporary trade facilitation, on the other hand, extends from "at the border" to "within the border", i.e., the main content adds logistics infrastructure, communication facilities, logistics performance, government governance capacity, and related service measures to the traditional trade facilitation [4]. At present, the WTO, APEC and the World Bank have introduced different indicator systems for evaluating and measuring trade facilitation. Since the evaluation system of trade facilitation indicators is more complex and the evaluation of its measurement is not unified in academic circles, the authors believe that before carrying out this study, it is necessary to combine the research subjects and make a scientific assessment of the trade facilitation evaluation system [5].

\subsection{Review of Research on the Impact of Trade Facilitation on Cross-Border E-Commerce Transactions}

Combing domestic and foreign research results, the research on trade facilitation can be divided into two major aspects: first, the analysis of the impact of trade facilitation on cross-border e-commerce transactions. Essentially, trade facilitation is the reduction of transaction costs through "institutional arrangements" involving multiple fields, which in turn generates trade creation and trade expansion effects, promotes the development of international trade, and further enhances the overall welfare of society [6,7]. Second, in terms of research methodology, the Global Trade Analysis Model (GTAP) and Computable General Equilibrium Model (CGE) are usually used to analyze and verify the effects of 
enhancing trade facilitation on trade flows, trade costs, e-commerce, capital investment, business opportunities, etc. Existing results carry out research on its contribution to trade growth from different perspectives, such as facilitation of customs clearance procedures, infrastructure construction standards, non-tariff barriers, port operation efficiency, domestic environmental regulations, and construction of free trade zones, laying an important foundation for the study in this paper $[8,9]$.

In summary, there is a great deal of literature on the impact of trade facilitation on cross-border e-commerce transactions, which provides important theoretical and factual basis for this study; however, results on cross-border e-commerce trade effects as the main body of research are not very common, and there is still the possibility of further in-depth excavation and expansion in the research content and research methods. Specifically, the construction of the evaluation system of trade facilitation first needs to be improved in terms of relevance. Second, the research subject is not micro-specific enough, and results of research on the impact of the scale effects of cross-border e-commerce trade are relatively rare. Third, the design of the research structure is not sufficiently considered, and the perspective is singular, without a comprehensive analysis of the impact and constraints from the perspective of differences in trade facilitation in bilateral trade countries.

In view of this, the present paper intends to first, carry out the design of a trade facilitation evaluation index system for bilateral countries based on transaction cost theory; second, construct a conceptual model of the impact of trade facilitation environment on cross-border e-commerce transactions; and third, use a dynamic panel model with interaction terms to verify the effects of trade facilitation measures such as cross-border transportation costs, cross-border customs clearance costs, political transaction costs and time costs on cross-border e-commerce trade Finally, the effects of trade facilitation measures such as cross-border transportation costs, cross-border customs clearance costs, political transaction costs and time costs on the scale of cross-border e-commerce trade will be further verified using the dynamic panel model to further explore the extent of the role of government-governance capacity on the customs clearance environment in the process of cross-border e-commerce transactions $[10,11]$.

\section{Construction of a Conceptual Model of the Impact of Trade Facilitation Based on Cross-Border Logistics Costs on the Scale Effect of Cross-Border E-Commerce Trade}

In the fields of new institutional economics and trade economy, transaction costs are usually interpreted as economic exchange costs, which can be broken down into two parts, "transaction" and "cost" [12]. Transaction refers to "the conversion of ownership of goods between individuals"; correspondingly, transaction costs are understood as the costs incurred by both parties to establish a relationship. Williamson believes that transaction costs are all the resources needed to negotiate, obtain business information, and execute contracts; that is, they include manager transaction costs incurred in the exercise of power within the company, market transaction costs incurred in the external market of the company, and operation and maintenance Political transaction costs incurred by the government's institutional framework can also be included. Although cross-border e-commerce is a new mode of international trade, transaction costs represented by crossborder logistics occupy an important position. Compared with traditional trade, the biggest advantage of cross-border e-commerce transactions lies in the saving of transaction costs, that is to say, the cost of information flow between the two parties in terms of business information acquisition, sharing, and exchange has been greatly reduced. However, crossborder e-commerce transactions are often sporadic and small items and groceries are mainly purchased in the form of daily consumer goods transactions; thus, higher requirements are often placed on the flow of goods. $[13,14]$ In this case, the cross-border logistics cost of related goods in cross-border e-commerce business is directly related to the logistics infrastructure, customs environment, and government-governance contexts of bilateral trade countries. These will directly affect the confidence of cross-border e-commerce traders and the scale of transactions via such paths as transport costs, time costs, political transaction costs and information costs $[15,16]$. 
In this way, information flow and capital flow for cross-border e-commerce transactions can be completed online, and their impact on transaction costs is relatively weakened, while logistics needs to be realized offline, and has become the bottleneck that restricts the trade cost of cross-border e-commerce transactions. Logistics costs include a wide range of content. According to the practical needs of cross-border e-commerce transactions, this article mainly discusses transportation costs, customs clearance costs, government-governance costs, and time costs.

\subsection{Analysis of Infrastructure Impact Based on Cross-Border Transportation Costs}

The cross-border transportation cost usually involves all the expenses for completing the transportation within a certain period of time. In cross-border e-commerce logistics, this cost is closely related to the quality of the national logistics infrastructure of both parties to the transaction [17]. Infrastructure refers to the quality and service capabilities of domestic and foreign ports and port infrastructure. Generally, it can be divided into two aspects: hardware and software infrastructure services in international trade, usually including the quality of seaports, airports, roads, railways and other infrastructures, and the capacity of loading and unloading and transshipment of transportation services. In practice, infrastructure is mainly reflected through facility quality, and facility quality as a qualitative concept can be quantified through a series of indicators [18].

Taking Khorgos port in Xinjiang as an example, as an important transportation node between China and Central Asian countries, the state has issued a series of supporting development policies for this port in recent years. With the improvement of logistics facilities, the efficiency of port functions has been rapidly improved, greatly enhancing the port's competitive advantage in cross-border trade and international transportation. With the increase in the number of China-Europe express trains, the volume of customs clearance trade has increased year by year (see Table 1).

Table 1. Statistics on the customs clearance trade volume at Khorgos port and the number of China-Europe trains opened from 2011 to 2019.

\begin{tabular}{cccccccccc}
\hline Time & $\mathbf{2 0 1 1}$ & $\mathbf{2 0 1 2}$ & $\mathbf{2 0 1 3}$ & $\mathbf{2 0 1 4}$ & $\mathbf{2 0 1 5}$ & $\mathbf{2 0 1 6}$ & $\mathbf{2 0 1 7}$ & $\mathbf{2 0 1 8}$ & $\mathbf{2 0 1 9}$ \\
\hline $\begin{array}{c}\text { Customs clearance trade } \\
\text { volume (US\$ billion) }\end{array}$ & 71 & 110 & 144 & 146 & 120 & 240 & 386 & 498 & - \\
\hline $\begin{array}{c}\text { Number of China-Europe } \\
\text { Class Trains Opened }\end{array}$ & 17 & 42 & 80 & 308 & 815 & 1702 & 3673 & 6300 & 8225 \\
\hline
\end{tabular}

For cross-border e-commerce transactions, the quality of infrastructure plays a more important role in the transfer of cargoes between the two sides; better logistics infrastructure in the bilateral trading countries results in stronger operational capacity, higher operational efficiency [19], higher quality of logistics services provided in the transaction process, and accordingly lower transportation costs, which help improve the overall quality and scale of a country's cross-border e-commerce transactions and realize the positive impact of the scale of cross-border e-commerce transactions [20]. Accordingly, this paper proposes hypothesis 1 as follows.

Hypothesis 1 (H1). Infrastructure development in countries along the route ("along the route" refers to the countries along the "Belt and Road", the same below.) has a positive effect on the scale of cross-border e-commerce by saving cross-border transportation costs.

\subsection{Analysis of the Impact of Customs Clearance Condition Based on the Cost of Cross-Border Customs Clearance}

Cross-border customs clearance is one of the necessary aspects of international trade activities, and all inbound and outbound goods must enter into circulation under customs supervision within a specified period and at a specified location $[21,22]$. The customs clearance environment is mainly an assessment of the customs regulatory environment, which 
is closely related to customs supervision and clearance management as well as commodity inspection, quarantine, and the origin regulatory environment, including specifically the complexity and transparency of customs clearance procedures management, the number of export documents, turnaround time, etc. Since the establishment of the first batch of cross-border e-commerce pilot zones in China in 2015, a total of 105 zones have been established in five batches, aiming to reduce the costs of logistics and customs clearance for cross-border e-commerce transactions in all aspects and to promote the experience and policies of cross-border e-commerce transactions. With innovative regulatory measures such as "advance declaration, goods inspection and release, simplified declaration, clearance and release, summary statistics", the scale of cross-border e-commerce transactions has been promoted $[23,24]$. According to Guangzhou Customs data, in the first four months of 2020 alone, the total import and export commodities supervised through the cross-border e-commerce management platform in the customs area was RMB 11.8 billion, an increase of $7 \%$ over the same period last year and accounting for $22.6 \%$ of the country.

In practical business, the quality of the environment of customs control in bilateral countries has a direct impact on e-commerce transactions, and the optimization of the customs control environment depends on the administrative control of both sides, i.e., on the preference for a transparent regulatory system and trade approval procedures. Therefore, it is very important to correctly assess the effectiveness of import and export procedures, the transparency of border management, the average number of days for customs clearance, the number of major document types and other import and export process efficiencies. In summary, the quality of the customs clearance environment will have a significant impact on the cross-border e-commerce trade effect. Therefore, this article proposes hypothesis 2 , as follows.

Hypothesis 2 (H2). The cross-border customs clearance environment of coastal countries positively affects the scale of cross-border e-commerce by reducing the cost of cross-border customs clearance.

\subsection{Analysis of the Impact of Government-Governance Capacity in Importing Countries Based on Political Transaction Costs}

Political transaction cost refers to the various resources consumed in the exchange of rights in the political sphere; such costs often arise due to information asymmetry, opportunism and asset specificity. Because the two sides in cross-border e-commerce transactions are located in countries with different political and institutional environments, the two sides of the transaction can easily generate asymmetric information and subsequently incur political transaction costs [25]. At this point, the government-governance environment of bilateral countries plays an important role in influencing the political transaction costs $[26,27]$. A good government-governance environment can introduce adaptive institutional policies, which can better maintain the order of national market operations, and helps domestic manufacturers to reduce production costs and transaction costs so that their products can have a competitive advantage in the international market competition and promote the development of national trade [28,29].

Government-governance capacity is also reflected in the control of corruption, and there is an important correlation between the level of government corruption and a country's foreign trade and economic situation [30]. It has been shown that in some less developed countries, unscrupulous businessmen influence the formulation and implementation of policy measures and even laws by, for example, bribing government officials. The deeper the level of corruption, the more likely it is that trade intervention will occur to protect and facilitate those who pay bribes [31]. In countries with a higher degree of democracy, government administration is often widely monitored and constrained by the public, and thus policy formulation, laws and regulations are relatively open and transparent. This environment is more conducive to trade liberalization and trade openness, which helps the implementation of liberal policies, thus making a country's trade environment more open [32,33]. 
In addition, according to classical free trade theory and institutional economics transaction cost theory, a more fair, transparent and open trading environment is conducive to the development of bilateral trade. Therefore, the effectiveness, transparency and reliability of trade policies and regulations of bilateral trade between countries can provide facilitation and support for trade promotion, and ensure the reduction of uncertainties in a country's customs clearance environment. Therefore, government-governance environment itself has a positive impact on the scale of cross-border e-commerce transactions while at the same time indirectly promoting the scale of cross-border e-commerce transactions through the continuous influence and improvement of the customs clearance environment. Therefore, this article proposes hypotheses $\mathrm{H} 3 \mathrm{a}$ and $\mathrm{H} 3 \mathrm{~b}$, as follows.

Hypothesis 3a (H3a). The government-governance capabilities of countries along the route promote the expansion of cross-border e-commerce trade by saving political transaction costs.

Hypothesis $\mathbf{3 b} \mathbf{b} \mathbf{H} 3 \mathbf{b})$. The governance capacity of the countries along the route promotes the impact of customs clearance on the scale of cross-border e-commerce.

\subsection{Analysis of the Impact of Cross-Border Logistics Services Based on Time Costs}

In transaction cost theory, time cost refers to the time that customers must spend to get the desired goods or services, converted into a cost; this cost may be the time cost of reaching an agreement, and may also be the transaction process due to the handover conversion inefficiency brought about by waiting, or caused by missed market opportunities. According to Khorgos Customs statistics, the average whole train changeover time of inbound and outbound China-Europe trains at Khorgos port has been reduced from an average of $6 \mathrm{~h}$ in 2017 to about $3.5 \mathrm{~h}$ now. In addition, the inbound and outbound China-Europe trains via Khorgos railroad port in 2019 amounted to 3403 trains, an increase of $65.60 \%$ year-on-year, with a freight volume of 3,135,100 tons, an increase of $71.86 \%$ year over year. For the January-May 2020 period, outbound China-Europe trains increased by $28.95 \%$ year over year, driving the cumulative export of cross-border e-commerce parcels at Alashankou Port to exceed 10 million pieces during the same period.

As can be seen, for cross-border e-commerce merchants it is very important to complete the delivery of high-value goods in a timely manner in order to minimize inventory backlog and improve circulation efficiency in order to ensure corporate cash flow and give full play to comparative cost advantages. For time costs, which are often hidden, they need to be evaluated in combination with order elapsed time, stock preparation time, shipment cycle and delivery time to customers. The essence of efficient cross-border e-commerce transactions in terms of time lies in the use of synchronized online and offline operations; however, if the exchange of goods between customers still needs to use offline logistics to complete the actual transmission, then the time cost remains subject to cross-border logistics services. Cross-border logistics services can be analyzed from the perspective, of either capacity or efficiency [25]. For capacity, the impact of the freight sector on cross-border logistics parcel tracking queries and freight service quality is examined; efficiency, specifically logistical efficiency, is usually explained as the ratio of input to output of logistics elements within a certain period, and represents the cost and efficiency of the whole process of freight logistics [32]. Therefore, this article proposes hypothesis 4 , as follows.

Hypothesis 4 (H4). Cross-border logistics services along the route have a positive effect on the scale of cross-border e-commerce trade by saving time and costs.

In summary, based on the four transmission paths under transaction costs, this paper constructs a conceptual model of the impact of trade facilitation environmental factors on the scale of cross-border e-commerce transactions represented by infrastructure, customs clearance environment, government-governance capabilities, and cross-border logistics services, and intends to introduce the interaction terms between government-governance capabilities and customs clearance environment into the model in order to verify the 
possible differences in the impact of different trade facilitation measures on the scale of cross-border e-commerce transactions (see Figure 2).

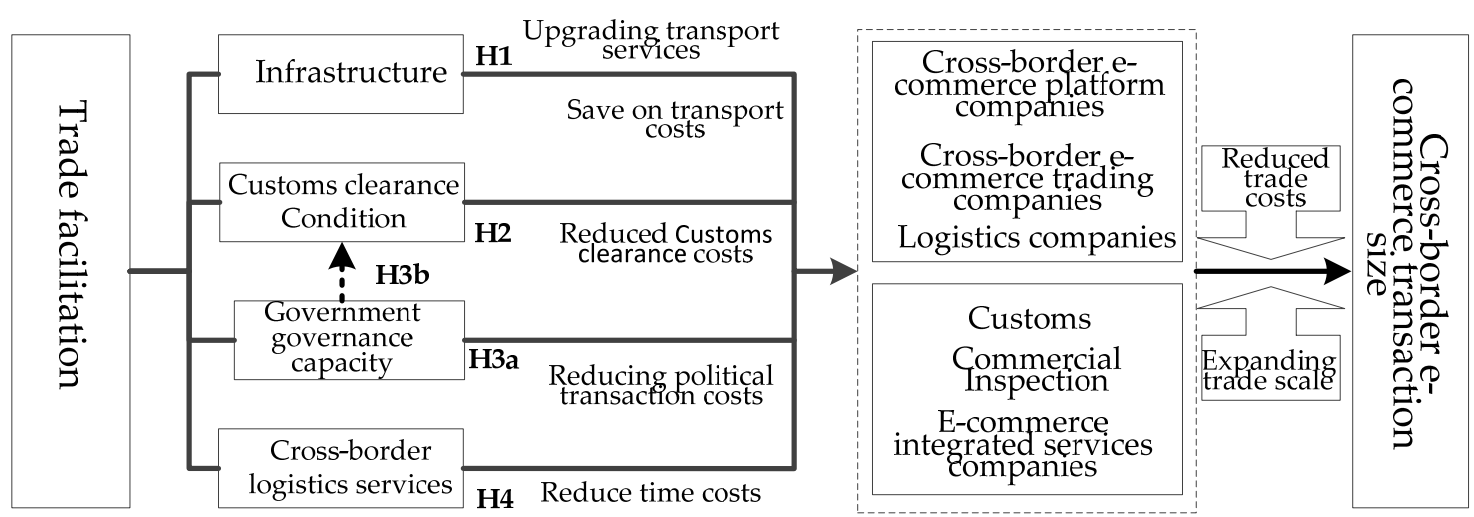

Figure 2. A path analysis framework for the impact of trade facilitation on the scale effect of cross-border e-commerce.

\section{Models and Data}

\subsection{Variable Selection and Data Source Description}

\subsubsection{Explained Variables}

This paper selects the trading partner countries along the "Belt and Road" with which China conducted cross-border e-commerce transactions between 2013 and 2019 (The sample period is set at 2013-2019 for two main reasons: first, data availability; second, this period coincides with the transition of China's cross-border e-commerce transactions from the growth phase to the maturity phase)as the sample countries (The sample countries are selected as the main destination countries of China's export cross-border e-commerce in the 2020 “B2C Cross-border E-commerce Platform Overseas Research Report", including: Russia, France, the United Kingdom, Brazil, Canada, Germany, Japan, South Korea, India, Thailand, Malaysia, Singapore, Indonesia, Kuwait, the UAE, Qatar and other 16 countries), and conducts a study on the impact of trade facilitation on the trade effect of cross-border e-commerce.

\subsubsection{Explanatory Variables}

Trade facilitation level indicators are the core explanatory variables in this paper. For the measurement of trade facilitation environment, this paper relies on the trade assessment system proposed by Wilson in 2003 based on four aspects of trade facilitation in each partner country, namely infrastructure, customs clearance environment, government-governance environment and cross-border logistics service capacity. The specific index selections and correspondences are shown in Table A1.

In addition, this article selects the number of postal international express orders (PIE), cross-border Internet payments (CBP), per capita GDP of trading partner countries (GDPE), broadband Internet users (ITP), etc., (Source of data for control variables: World Bank Database) as control variables in order to carry out empirical verification and analysis.

\subsection{Econometric Model Construction}

Based on transaction cost theory in combination with the previous analysis, it can be seen that the impact of trade facilitation environment on cross-border e-commerce transactions unfolds through different transmission paths. To ensure the conciseness of the empirical analysis process, this paper first uses principal component analysis to calculate the quantitative values of each path, such as infrastructure, customs clearance environment, government-governance environment, and cross-border logistics service capacity, and then uses them as explanatory variables in the model regression. Before the model regression, all variables are taken as natural logarithms to effectively reduce the heteroskedasticity of the model. Considering that the growth of cross-border e-commerce transaction scale has a certain time continuity, i.e., the current period's cross-border e- 
commerce transaction scale is influenced by that of the previous period, and considering the endogeneity problem caused by the possible omission of variables, the lagged period of the explained variables is introduced as an explanatory variable in the model, i.e., the dynamic panel data econometric regression model (Equation (1)) is constructed as follows:

$$
\begin{aligned}
& \operatorname{LnTrade}_{i t}=\alpha_{0}+\rho \operatorname{LnTrade} \operatorname{Tit-1}_{1}+\beta_{1} L n L F_{i t}+\beta_{2} \operatorname{LnC} E_{i t}+\beta_{3} L n G E_{i t} \\
& +\beta_{4} \operatorname{LnLS} S_{i t}+X_{i t}+\varepsilon_{i t} \\
& X_{i t}=\theta_{1} \operatorname{LnPIE}+\theta_{2} \operatorname{LnCBP}+\theta_{3} \operatorname{LnGDPE_{it}}+\theta_{4} \operatorname{LnITP} P_{i t}
\end{aligned}
$$

where the subscript $i$ represents the country and $t$ represents the year. Lntrade is the explanatory variable, indicating the scale of cross-border e-commerce transactions in each country; Lntrade $_{i, t-1}$ is the period after the explanatory variable; $L n L F, L n C E, L n G E$, and $L n L E$ represent the level of infrastructure, customs clearance environment, government governance capacity, and cross-border logistics service capacity, respectively; $X$ is the control variable; and $\varepsilon$ is the random error term, which varies simultaneously with time and individuals.

Equation (1) is the base regression model of this paper, taking into account that trade facilitation is one of the multiple factors that promote the effect of cross-border e-commerce trade, and the existing trade facilitation evaluation measurement data are subjective data, which cannot measure absolute amounts in the same way as factual data; in order to better verify the relationship between them, it is therefore appropriate to use the amount of change to measure the analysis at the same time, in order to eliminate the individual effects in the model and to alleviate the effects of multicollinearity between the explanatory variables both in Equation (1) (This article first standardizes the indicators under the five paths, and then uses the principal component analysis method to select the first two principal components that cumulatively explain $60 \%$ or more of the change in the above difference to perform a weighted average so as to obtain the core indicators for measuring each path. Due to space limitations, the calculation results of each principal component score and contribution rate are not provided here) and the common time trend between variables, etc. Thus, perform log differencing on Equation (1) to get regression Equation (2).

$\Delta$ LnTrade $_{i t}=\rho \operatorname{LnTrade}_{i t-1}+\beta_{1} \Delta L n L F_{i t}+\beta_{2} \Delta L n C E_{i t}+\beta_{3} \Delta L n G E_{i t}+\beta_{4} \Delta L n L S_{i t}+\Delta X_{i t}+\Delta \varepsilon_{i t}$

At the same time, in order to verify for the influence of government-governance capacity in the customs clearance environment on the scale of cross-border e-commerce transactions, the model introduces the interaction term between government-governance capacity and customs clearance environment to obtain the regression Equation (3).

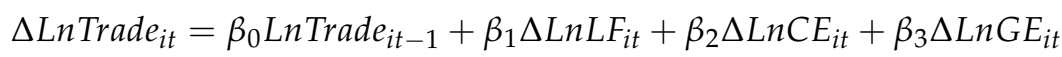

$+\beta_{4} L n L S_{i t}+\beta_{5} \Delta L n G E_{i t} \times \Delta L n C E_{i t}+\Delta X_{i t}+\Delta \varepsilon_{i t}$

\subsection{Estimation Method Determination}

In Equation (1), the explanatory variable is lagged by one period as the explanatory variable; this model construction belongs to the typical dynamic panel model. The advantage of a dynamic panel is that it better solves the endogeneity problem that tends to exist in the traditional fixed-effects and random-effects model panel data models; however, the model is vulnerable to the interference of heteroskedasticity in the model. In order to avoid bias in the regression results, this paper proposes to adopt a two-step systematic generalized moment estimation, i.e., a systematic GMM approach, in the selection of estimation methods in order to obtain consistent and valid GMM model estimates. The model also needs to be tested for the validity of instrumental variables, i.e., the Hansen test and the correlation test of residual terms.

In addition, it should be noted that the model includes five main explanatory variables: trade facilitation indicators and their interaction terms, the first-order lags of the explanatory variables, and control variables such as cross-border Internet payments, GDP per capita, and broadband Internet users. Most of these explanatory variables are closely 
associated with changes in the size of a country's cross-border e-commerce transactions; see the Pearson correlation coefficient matrix in Table A2 for details.

\subsection{Model Estimation and Analysis of Results}

The regressions of Equations (1)-(3) were conducted using Stata15 software; the empirical results are shown in Table A3. In particular, SYS-GMM is the core analytical model used to facilitate comparison and to carry out robustness tests of the model. The estimation results of mixed OLS regression, fixed effects regression, random effects regression and differential GMM are also presented in Table A3.

Looking at the overall regression results in Table A3, the model first estimates the two key tests of validity in the systematic GMM estimation method. In particular, the p-value for the $\operatorname{AR}(2)$ test is 0.310 , indicating that there is no second-order serial correlation in the residual terms. The p-value for the Hansen test statistic is 0.438 , which is greater than the commonly set critical value of 0.05 ; thus, all instrumental variables are valid. The $\mathrm{R}^{2}$ values of the regression models are $0.7466,0.7587,0.7707$ and 0.8318 respectively, with generally low $\mathrm{R}^{2}$ values. The main reasons for this analysis may be due first to the data of the explanatory and explained variables containing both factual and subjective data, as the simultaneous occurrence of such different types of data will likely lead to this result, and second to the trade facilitation evaluation indicators in the explanatory variables, as the human and social capital factor included in the explanatory variables is difficult to measure and quantify, and subjective evaluation data must be used as a substitute. However, with the introduction of the cross-sectional term, the $\mathrm{R}^{2}$ value increases significantly, indicating that the explanatory power of the model has been enhanced. In terms of the regression coefficients of the control variables, the explanatory variables with a lag of one period are significantly positive and the regression coefficients are less than one, which is consistent with the actual situation and helps to ensure the overall explanatory power of the model. In addition, all three control variables also show a significant positive contribution to the growth of cross-border e-commerce transaction size, which is more in line with both the theoretical and practical situations.

From the regression results of the DIFF-GMM model, the overall quality of infrastructure, customs clearance environment, government-governance capacity, and cross-border logistics services in trade facilitation measures all have a significant positive effect on the scale of cross-border e-commerce transactions in each path, i.e., hypotheses H1, H2, H3a and $\mathrm{H} 4$ are all supported. Meanwhile, in the SYS-GMM regression, infrastructure, customs clearance environment and government-governance capacity show a stronger influence. This suggests that for a new trade model such as cross-border e-commerce, the smooth conduct of transactions depends first and foremost on the maturity of logistics support facilities in bilateral countries. While cross-border e-commerce transactions are growing at a rapid pace, the smooth flow of every node in the supply chain should be ensured. Secondly, cross-border e-commerce transactions also require high efficiency in customs clearance, as the efficiency and construction level of customs in terms of the time taken to clear goods, the frequency of inspection and clearance methods, and the intelligence and informatization of ports directly affect the cost of clearance for cross-border e-commerce transactions. This means that there is a need to create a more streamlined customs clearance environment and regulatory environment for cross-border e-commerce.

At present, the country is vigorously developing the construction of free trade zones and comprehensive pilot zones for cross-border e-commerce, providing a higher level, more preferential policies and a more simplified one-stop service platform for cross-border e-commerce through preferential trade arrangements in free trade zones and providing solutions and professional information support for the global supply chain by, i.e., optimizing the customs clearance environment at ports, improving the efficiency of cargo clearance and reducing the cost of customs clearance for enterprises to achieve substantial Support.

This is all premised on the improvement of the government's governance capacity, which is further evidenced by the regression results of the interaction term in the SYS-GMM 
model. The positive coefficient of the interaction term indicates that governance capacity not only contributes to the smooth running of cross-border e-commerce transactions on its own, but also brings about the expansion of cross-border e-commerce transactions by influencing the customs clearance environment. The stronger and more efficient the governance capacity, the more likely it is in practice to provide more preferential and transparent trade policies and convenient trade measure arrangements for importers and exporters; thus, hypothesis H3b holds and the trade promotion effect of governmentgovernance capacity on cross-border e-commerce transactions is evident and empirically verified by the data.

It should be noted that while the coefficients of the above explanatory variables can indicate the impact of the trade promotion effect on the scale of cross-border e-commerce transactions from their respective paths and perspectives and clarify the important role of government governance capacity in the impact path, they have not yet been explored in terms of the total impact of this trade facilitation condition on cross-border e-commerce transactions. To this end, this paper will further examine the overall impact by specifically examining the impact government-governance capacity on the scale of cross-border ecommerce transactions by calculating the value of the bias effect in the model. According to Equation (3) in this paper, the partial derivative can be obtained from the bias effect Equation (4), as follows:

$$
\frac{\partial \Delta \operatorname{LnTrade}_{i t}}{\partial \Delta \operatorname{LnG} E_{i t}}=\beta_{3 i t}+\beta_{5} \Delta \operatorname{LnC} E_{i t}
$$

The partial effect of government governance capacity on the trade promotion effect of cross-border e-commerce transactions can then be calculated according to Equation (4) (In model (4), $\triangle \ln C E$ is calculated using the mean of the difference variables of the logarithm of the change in customs environment for the full sample of countries, and the calculation represents a bias effect based on the mean level); from the calculation results in Table A3, it can be seen that the partial effect of government-governance capacity on the trade promotion effect of cross-border e-commerce transactions is 4.0147 ( $\triangle \ln C E$ uses the mean of the difference variables of the logarithm of the quantile values of the full sample, and therefore represents a bias effect at the mean level.). These calculation results indicate that government-governance capacity has a significant trade promotion effect on cross-border e-commerce transactions, and the trade promotion effect is high and very clear.

\subsection{Robustness Tests}

From the regression results of each econometric model in Table A3, it can be seen that although the explanatory variables have slightly different regression results and significance in each model, the significance and coefficient signs of cross-border logistics services, customs clearance environment and government-governance indicators are the same, and there are differences only in the degree of significance and coefficient size; thus, the above regression results have clear robustness. To further prove the robustness of the empirical validation conclusion, we regressed again with the relative proportion of the cross-border e-commerce export (import) transaction scale as the explanatory variable. In the regression results of the SYS-GMM model of the robustness test, there is no secondorder serial autocorrelation in the AR(2) test, and the p-values of the instrumental variable validity test statistics are all higher than $5 \%$; thus, the estimation results of the model are considered to be reasonably valid. The regression results show that although there are still slight differences in the estimated results of each explanatory variable in each model, the two indicators of infrastructure and government-governance still show high significant effects among the four trade facilitation environment indicators, which indicates that the regression results of the robustness test model with the proportion of cross-border e-commerce transaction scale as the explanatory variable also have clear robustness. 


\section{Conclusions and Policy Recommendations}

\subsection{Conclusions}

In this paper, we have conducted a study on the impact of trade facilitation on the trade scale effect of cross-border e-commerce transactions, using dynamic panel data based on interaction terms around four types of trade facilitation environmental factors: logistics facilities, customs clearance environment, government-governance environment, and logistical efficiency. The research returned the following results.

First, the trade facilitation environment is constrained and influenced by four paths, transport costs, time costs, customs clearance costs and political transaction costs, which affect the expansion of a country's cross-border e-commerce transactions. Second, among the different paths and factors affecting the trade facilitation environment the impact of infrastructure quality varies greatly, which shows that the improvement of logistics infrastructure plays an important role in the expansion of cross-border e-commerce trade on both sides. This further demonstrates that China is right to give top priority to infrastructure connectivity in "Belt and Road" construction. Third, the skewed effect shows that the level of governance has significantly contributed to the improvement of the customs clearance environment and trade facilitation.

\subsection{Policy Recommendations}

Under the current situation of increasingly complex international supply chains, designing effective trade facilitation environment improvement measures is a realistic need to adapt to the sustainable development of cross-border e-commerce. The findings of this paper will provide a reference for the development and improvement of relevant measures to optimize the trade facilitation environment.

First, it is necessary to further accelerate the improvement of port infrastructure construction and to promote the interconnection of infrastructure.

The government should continue to increase the construction and investment of domestic port infrastructure, and especially accelerate the construction of free trade zones around the region as a reference point, as well as strongly support inter-regional interconnection. Strengthening financial and technical support for the construction of ports, land and railroad infrastructure with countries in Southeast Asia and West Asia in order to realize the interconnection and interoperability of infrastructure with countries along the route is also desirable.

Second, the customs environment should be optimized, promoting customs clearance facilitation and intelligence and strengthening cross-border inter-customs cooperation.

Continuously deepening bilateral and multilateral customs clearance cooperation under the leadership of the government and strengthening docking and customs clearance rules with ASEAN countries and countries along "The Belt and Road" through the construction of cross-border e-commerce pilot zones and free trade zones will further accelerate the construction of the port management sharing platform and improve the intelligence of port management.

Third, on the basis of the existing government administrative management advantages, improving governance capacity will contribute to the excellence of the trade environment.

On the one hand, the government should take advantage of current administration to comprehensively strengthen the combining of global supply chains, cut administrative intervention in trade policies, and appropriately reduce and decentralize power, while at the same time resolutely resisting corruption in order to create service-efficient governance. On the other hand, through an appropriately relaxed foreign exchange control policy, the government should relax the management of the virtual accounts of foreign payment institutions for cross-border e-commerce and simplify filing, account opening and reporting, etc., as reducing the complexity of these procedures and processes facilitates the operation of enterprise funds. 


\subsection{Research Limitations and Prospects}

Based on the analysis of trade costs, this article takes countries along the "Belt and Road" as the main body and cross-border e-commerce transactions between China and the countries along the route as the core in exploring the influence path of trade facilitation measures in the expansion of the scale of cross-border e-commerce transactions between China and countries along the route and drawing preliminary research conclusions. The findings of the study have laid an important theoretical foundation for the study of the trade expansion effects of trade facilitation, trade costs, etc., and the scale of cross-border e-commerce transactions. On the basis of this paper, subsequent studies can be considered which will go deeper and expand on the following two aspects. First, the analysis of the impact of government capacity on the influence mechanism of cross-border e-commerce trade expansion can be deepened. This study has analysed and verified the mechanism of the role and influence effect of government-governance capacity; however, there is no specific node at which the government's ability to govern plays an effective role. In the future, if the data are available, a similar analysis and validation can be carried out by expanding the sample of countries. It would also be worthwhile to explore the direction of the differential economic development level of the target countries.

Author Contributions: Conception and design of trade facilitation mechanisms, Y.L.; Methodology and model construction, L.G. and J.L.; Data collection, S.Z.; Literature synthesis, X.F.; Writing review and editing, Y.L. All authors have read and agreed to the published version of the manuscript.

Funding: This paper is the result of Liaoning Provincial Higher Education Innovation Talent Support Program; The project of Liaoning Provincial Social Science Foundation: Study on High Quality Direct Investment by Enterprises in Countries along the Belt and Road from the Perspective of Human Destiny Community (L21BGJ005).

Institutional Review Board Statement: Not applicable.

Informed Consent Statement: Not applicable.

Data Availability Statement: The data presented in this study is available on request from the corresponding author.

Conflicts of Interest: The authors declare no conflict of interest.

\section{Appendix A}

Table A1. Description of indicators for each explanatory variable.

\begin{tabular}{|c|c|c|c|c|}
\hline Type of Indicator & Tier 1 Indicator Name & Tier 2 Indicator Name & Explanation of Indicators & Data Sources \\
\hline Explanatory variables & - & $\begin{array}{l}\text { Cross-border e-commerce } \\
\text { transaction size }\end{array}$ & $\begin{array}{c}\text { Import and } \\
\text { export transactions }\end{array}$ & $\begin{array}{l}\text { Net Energy's Cross Border } \\
\text { E-Commerce Research } \\
\text { Centre Database }\end{array}$ \\
\hline \multirow{3}{*}{$\begin{array}{l}\text { Cross-border } \\
\text { transport costs }\end{array}$} & \multirow{3}{*}{$\begin{array}{c}\text { H1: } \\
\text { Infrastructure (LF) }\end{array}$} & $\begin{array}{l}\text { Freight terminal } \\
\text { throughput }\end{array}$ & TEU (number of TEUs) & EPS database \\
\hline & & Quality of infrastructure & $1-5(1=$ low, 5 = high $)$ & EPS database \\
\hline & & $\begin{array}{l}\text { National highway } \\
\text { infrastructure construction } \\
\text { along the Belt and Road }\end{array}$ & $1-7$ (1 = low, 7 = high $)$ & WEF_Global Compet \\
\hline \multirow{4}{*}{$\begin{array}{l}\text { Cross-border customs } \\
\text { clearance costs }\end{array}$} & \multirow{4}{*}{$\begin{array}{l}\mathrm{H} 2: \\
\text { Customs clearance } \\
\text { environment }(\mathrm{CE})\end{array}$} & $\begin{array}{c}\text { Burden of } \\
\text { customs procedures }\end{array}$ & $1-7(1=$ low, 7 = high $)$ & $\begin{array}{c}\text { WEF_Global } \\
\text { Competitiveness Report }\end{array}$ \\
\hline & & Cargo turnaround time & Number of days & EPS database \\
\hline & & $\begin{array}{l}\text { Number of } \\
\text { export documents }\end{array}$ & Number & EPS database \\
\hline & & $\begin{array}{l}\text { Average time for customs } \\
\text { clearance of exports }\end{array}$ & Number of days & EPS database \\
\hline
\end{tabular}


Table A1. Cont.

\begin{tabular}{|c|c|c|c|c|}
\hline Type of Indicator & Tier 1 Indicator Name & Tier 2 Indicator Name & Explanation of Indicators & Data Sources \\
\hline \multirow{3}{*}{$\begin{array}{c}\text { Political } \\
\text { transaction costs }\end{array}$} & \multirow{3}{*}{$\begin{array}{c}\text { H3a: } \\
\text { Government-governance } \\
\text { capacity (GE) }\end{array}$} & $\begin{array}{l}\text { The burden of } \\
\text { government regulations }\end{array}$ & $1-7(1=$ low, 7 = high $)$ & $\begin{array}{c}\text { WEF_Global } \\
\text { Competitiveness Report }\end{array}$ \\
\hline & & $\begin{array}{l}\text { Government policy } \\
\text { transparency }\end{array}$ & 1-7 (1 = low, 7 = high $)$ & $\begin{array}{c}\text { WEF_Global } \\
\text { Competitiveness Report }\end{array}$ \\
\hline & & Incidence of bribery & $\begin{array}{l}\text { Account for at least one } \\
\text { bribe payment request } \\
\text { experienced by } \\
\text { the company }(\%)\end{array}$ & EPS database \\
\hline \multirow{3}{*}{ Time costs } & \multirow{3}{*}{$\begin{array}{c}\text { H4: } \\
\text { Cross-border logistics } \\
\text { services (LS) }\end{array}$} & $\begin{array}{l}\text { Cross-border logistics } \\
\text { tracking query } \\
\text { Cargo capacity }\end{array}$ & $1-5(1=$ low, 5 = high $)$ & EPS database \\
\hline & & $\begin{array}{l}\text { Cross-border logistics } \\
\text { services Capacity } \\
\text { and quality }\end{array}$ & $1-5(1=$ low, 5 = high $)$ & EPS database \\
\hline & & $\begin{array}{l}\text { The frequency of } \\
\text { cross-border } \\
\text { transportation of goods at } \\
\text { the scheduled time to } \\
\text { reach the consignee }\end{array}$ & $1-5$ (1 = low, 5 = high $)$ & EPS database \\
\hline \multirow{4}{*}{$\begin{array}{l}\text { Control } \\
\text { variable }\end{array}$} & - & $\begin{array}{l}\text { Cross-border internet } \\
\text { payment volume }\end{array}$ & RMB billion & $\begin{array}{c}\text { Statistics of China } \\
\text { Payment and Clearing } \\
\text { Association and "Research } \\
\text { Report on Third-Party } \\
\text { Cross-border } \\
\text { Payment Industry" }\end{array}$ \\
\hline & - & $\begin{array}{l}\text { Number of postal } \\
\text { international } \\
\text { express orders }\end{array}$ & Number of pieces & $\begin{array}{l}\text { Universal Postal Union } \\
\text { Postal statistics }\end{array}$ \\
\hline & - & Internet users & Number of people & World Bank Datebase \\
\hline & - & GDP per capita & US\$ million & World Bank Datebase \\
\hline
\end{tabular}

Table A2. Correlation coefficient matrix of independent variables.

\begin{tabular}{|c|c|c|c|c|c|c|c|c|}
\hline & $L n L F$ & $\operatorname{LnCE}$ & $L n G E$ & LnLS & LnPIE & $\operatorname{LnCBP}$ & LnGDPE & LnITP \\
\hline $\operatorname{LnLF}$ & 1.000 & & & & & & & \\
\hline $\operatorname{LnCE}$ & $0.404^{* *}$ & 1.000 & & & & & & \\
\hline $\operatorname{LnGE}$ & $0.358 *$ & $0.865^{* *}$ & 1.000 & & & & & \\
\hline LnLS & $0.425^{* *}$ & 0.620 * & 0.183 * & 1.000 & & & & \\
\hline LnPIE & $0.782 *$ & $0.341^{* * *}$ & $-0.298 *$ & $-0.185^{* *}$ & 1.000 & & & \\
\hline $\operatorname{LnCBP}$ & $-0.595^{*}$ & $-0.356^{* *}$ & $-0.387^{* *}$ & $-0.457^{*}$ & $-0.158^{* *}$ & 1.000 & & \\
\hline LnGDPE & $0.575^{* * *}$ & 0.609 ** & $0.398^{* * *}$ & $0.308^{*}$ & 0.236 ** & $-0.288^{*}$ & 1.000 & \\
\hline LnITP & $0.386^{* * *}$ & $0.277^{*}$ & $0.262 *$ & $0.669^{* *}$ & $-0.209 *$ & $-0.335^{* *}$ & 0.304 * & 1.000 \\
\hline
\end{tabular}

Note: ${ }^{* * *}, * * *$ denote significant at the $10 \%, 5 \%$, and $1 \%$ significance levels; the correlation calculation includes data from all 16 sample countries from 2013 to 2019 .

Table A3. Model estimation results of the effect of trade facilitation on the trade effect of cross-border e-commerce.

\begin{tabular}{|c|c|c|c|c|c|}
\hline $\begin{array}{c}\text { Independent } \\
\text { Variable }\end{array}$ & Hybrid OLS (1) & $\begin{array}{l}\text { FE } \\
(2)\end{array}$ & $\begin{array}{l}\text { RE } \\
\text { (3) }\end{array}$ & $\begin{array}{c}\text { DIFF-GMM } \\
\text { (4) }\end{array}$ & $\begin{array}{c}\text { SYS-GMM } \\
\text { (5) }\end{array}$ \\
\hline L. $\ln T R A D E$ & & $0.1346^{* *}$ & 0.1801 * & $\begin{array}{c}0.1524 \text { * } \\
0.0017\end{array}$ & $\begin{array}{c}0.2002^{* * *} \\
0.0035\end{array}$ \\
\hline$\triangle L n L F$ & $\begin{array}{l}3.0211 \\
(-1.56)\end{array}$ & $\begin{array}{l}2.9014 * \\
(-2.47)\end{array}$ & $\begin{array}{c}2.0357 * * \\
(-2.78)\end{array}$ & $\begin{array}{l}2.1170^{* *} \\
(-2.06)\end{array}$ & $\begin{array}{c}2.8557 * \\
(1.95)\end{array}$ \\
\hline$\triangle L n C E$ & $\begin{array}{l}-1.9014^{*} \\
(2.37)\end{array}$ & $\begin{array}{c}-0.2241^{* *} \\
(1.98)\end{array}$ & $\begin{array}{c}-0.1897^{*} \\
(2.47)\end{array}$ & $\begin{array}{c}-0.2041 \text { * } \\
(2.06)\end{array}$ & $\begin{array}{c}-2.3507^{* * * *} \\
(-2.17)\end{array}$ \\
\hline$\triangle L n G E$ & $\begin{array}{l}2.0109 * \\
(-2.14)\end{array}$ & $\begin{array}{c}2.3056^{* *} \\
(-2.36)\end{array}$ & $\begin{array}{c}0.5874^{* *} \\
(2.45)\end{array}$ & $\begin{array}{c}0.7013^{* * *} \\
(1.96)\end{array}$ & $\begin{array}{c}2.3058^{* * * *} \\
(-2.03)\end{array}$ \\
\hline
\end{tabular}


Table A3. Cont.

\begin{tabular}{|c|c|c|c|c|c|}
\hline $\begin{array}{c}\text { Independent } \\
\text { Variable }\end{array}$ & Hybrid OLS (1) & $\begin{array}{l}\text { FE } \\
(2)\end{array}$ & $\begin{array}{l}\text { RE } \\
\text { (3) }\end{array}$ & $\begin{array}{c}\text { DIFF-GMM } \\
\text { (4) }\end{array}$ & $\begin{array}{c}\text { SYS-GMM } \\
\text { (5) }\end{array}$ \\
\hline$\Delta L n L S$ & $\begin{array}{l}0.1851^{* *} \\
(5.99)\end{array}$ & $\begin{array}{l}2.2381 * * \\
(2.69)\end{array}$ & $\begin{array}{l}2.2307 * \\
(2.03)\end{array}$ & $\begin{array}{l}2.2001 * \\
(2.51)\end{array}$ & $\begin{array}{c}0.1943^{* * *} \\
(0.96)\end{array}$ \\
\hline C & $\begin{array}{c}0.1874 \\
(3.23)\end{array}$ & $\begin{array}{l}0.1667 \\
(4.46)\end{array}$ & $\begin{array}{c}0.1790 \\
(3.81)\end{array}$ & $\begin{array}{l}0.5774^{* *} \\
(-1.88)\end{array}$ & $\begin{array}{c}0.9730 \text { ** } \\
(2.30)\end{array}$ \\
\hline$\Delta L n P I E$ & $\begin{array}{c}0.1670 * \\
(0.43)\end{array}$ & $\begin{array}{c}0.9311 * \\
(2.56)\end{array}$ & $\begin{array}{c}0.705 * \\
(1.96)\end{array}$ & $\begin{array}{l}0.3931^{* *} \\
(2.37)\end{array}$ & $\begin{array}{c}0.2784^{* * *} \\
(2.59)\end{array}$ \\
\hline$\triangle \operatorname{LnCBP}$ & $\begin{array}{c}0.1868 \\
(0.86)\end{array}$ & $\begin{array}{c}0.9041 \\
(1.99)\end{array}$ & $\begin{array}{c}0.7780 * \\
(1.87)\end{array}$ & $\begin{array}{c}0.5033^{* *} \\
(1.09)\end{array}$ & $\begin{array}{c}0.1859 * * * \\
(2.38)\end{array}$ \\
\hline$\triangle L n G D P E$ & $\begin{array}{c}0.4104 \\
(-1.87)\end{array}$ & $\begin{array}{c}0.1752 \\
(-1.98)\end{array}$ & $\begin{array}{c}0.1492 \text { * } \\
(0.57)\end{array}$ & $\begin{array}{l}0.1998^{* *} \\
(0.68)\end{array}$ & $\begin{array}{c}0.0307 * * * \\
(-2.08)\end{array}$ \\
\hline$\Delta \operatorname{LnITP}$ & $\begin{array}{l}1.5807 \\
(-0.91)\end{array}$ & $\begin{array}{l}1.2098 \\
(-1.47)\end{array}$ & $\begin{array}{l}1.2049 \\
(-2.05)\end{array}$ & $\begin{array}{l}1.4507 * \\
(-2.06)\end{array}$ & $\begin{array}{l}1.3368 * \\
(-2.87)\end{array}$ \\
\hline $\mathrm{t}$ & $\begin{array}{l}-0.0004 \\
(-2.22)\end{array}$ & $\begin{array}{l}-0.0006 \\
(-2.38)\end{array}$ & $\begin{array}{l}-0.0004 \\
(-2.51)\end{array}$ & $\begin{array}{l}-0.0001 \\
(-0.96)\end{array}$ & $\begin{array}{l}-0.0005 \\
(-0.08)\end{array}$ \\
\hline Constant term & $\begin{array}{c}12.0328 \\
(3.38)\end{array}$ & $\begin{array}{c}15.523 * \\
(5.64)\end{array}$ & $\begin{array}{c}17.3667 * \\
(-4.02)\end{array}$ & $\begin{array}{c}10.0014 \text { ** } \\
(-1.88)\end{array}$ & $\begin{array}{c}12.3640 * * \\
(5.21)\end{array}$ \\
\hline $\mathrm{R}^{2}$ & 0.4947 & 0.7466 & 0.7587 & 0.7707 & 0.8318 \\
\hline F/Wald & 187.43 & 160.29 & $(1.333$ & 601.75 & 799.80 \\
\hline (P) & $(0.0000)$ & $(0.0000)$ & $(0.0000)$ & $(0.0000)$ & $(0.0000)$ \\
\hline AR(1) test & & 0.0000 & 0.0000 & 0.0000 & 0.0000 \\
\hline AR(2) test & & 0.404 & 0.436 & 0.598 & 0.293 \\
\hline Hansan test & & 0.368 & 0.401 & 0.398 & 0.438 \\
\hline $\begin{array}{c}\text { Observed values } \\
\Delta L n G E i t \text { bias effect }\end{array}$ & 1344 & 1344 & 1344 & 1232 & $\begin{array}{c}1232 \\
4.0147\end{array}$ \\
\hline
\end{tabular}

Note: $* * * * *$ denote significance at the $10 \%, 5 \%$, and $1 \%$ significance levels, respectively, and the values in parentheses are the $t$-statistics of the corresponding estimates; "C" is the crossover term, $\mathrm{C}=\Delta \operatorname{LnCE} \times \triangle \operatorname{LnGE}$; FE is estimated using the clustering robust standard error method, and DIFF-GMM and SYS-GMM are estimated using the two-step robust standard error method; The DIFF-GMM and SYS-GMM differential equations include the first-order lags of the explanatory variables and the first- to third-order lags of all explanatory variables as instrumental variables, respectively, the level equation of SYS-GMM introduces the first-order differences of all explanatory variables as instrumental variables, and the Collapse function is used to control the instrumental variables to avoid biasing the estimation results due to too many instrumental variables; Regarding the treatment of missing values in the sample, this paper uses the mean values of the previous and subsequent years as data to add to the dataset.

\section{References}

1. Portugal-Perez, A.; Wilson, J.S. Export Performance and Trade Facilitation Reform: Hard and Soft Infrastructure. World Dev. 2012, 40, 1295-1307. [CrossRef]

2. Wang, S.; Lu, B.; Yin, K. Financial development, productivity, and high-quality development of the marine economy. Mar. Policy 2021, 130, 104553. [CrossRef]

3. Wang, S.; Zhao, D.; Chen, H. A spatial analysis of corruption, misallocation, and efficiency. Environ. Sci. Pollut. Res. 2020, 27, 36845-36856. [CrossRef]

4. Wang, S.; Yu, H.; Song, M. Assessing the efficiency of environmental regulations of large-scale enterprises based on extended fuzzy data envelopment analysis. Ind. Manag. Data Syst. 2018, 118, 463-479. [CrossRef]

5. Beverelli, C.; Neumueller, S.; Teh, R. Export Diversification Effects of the WTO Trade Facilitation Agreement. World Dev. 2015, 76, 293-310. [CrossRef]

6. Wang, S.; Sun, X.; Song, M. Environmental Regulation, Resource Misallocation, and Ecological Efficiency. Emerg. Mark. Finance Trade 2021, 57, 410-429. [CrossRef]

7. Bagwell, K.; Staiger, R.W. Multilateral trade negotiations, bilateral opportunism and the rules of GATT/WTO. J. Int. Econ. 2004, 63, 1-29. [CrossRef]

8. Saslavsky, D.; Shepherd, B. Facilitating international production networks: The role of trade logistics. J. Int. Trade Econ. Dev. 2013, 23, 979-999. [CrossRef]

9. Devlin, J.; Yee, P. Trade logistics in developing countries: The case of the Middle East and North Africa. World Econ. 2005, 28, 435-456. [CrossRef]

10. Wang, S.; Zhao, D.; Chen, H. Government corruption, resource misallocation, and ecological efficiency. Energy Econ. 2020, 85, 104573. [CrossRef]

11. Engman, M. The Economic Impact of Trade Facilitation. OECD Trade Policy Pap. 2005, 92-128. [CrossRef]

12. Kalnina, I.; Xiu, D. Nonparametric Estimation of the Leverage Effect: A Trade-off between Robustness and Efficiency. J. Am. Stat. Assoc. 2015, 112, 384-396. [CrossRef] 
13. Munir, K.; Ameer, A. Effect of economic growth, trade openness, urbanization, and technology on environment of Asian emerging economies. Manag. Environ. Qual. Int. J. 2018, 29, 1123-1134. [CrossRef]

14. Helble, M.; Mann, C.L.; Wilson, J.S. Aid-for-trade facilitation. Rev. WorldEcon. 2012, 148, 357-376. [CrossRef]

15. Wang, S.-H.; Song, M.-L.; Yu, T. Hidden Carbon Emissions, Industrial Clusters, and Structure Optimization in China. Comput. Econ. 2019, 54, 1319-1342. [CrossRef]

16. Marti, L.; Puertas, R. The importance of export logistics and trade costs in emerging economies. Marit. Econ. Logist. 2017, 19, 315-333. [CrossRef]

17. Sakyi, D.; Villaverde, J.; Maza, A.; Bonuedi, I. The Effects of Trade and Trade Facilitation on Economic Growth in Africa? Afr. Dev. Rev. 2017, 29, 350-361. [CrossRef]

18. Wang, S.; Song, M. China Environmental Economic Development Research Report 2019: Boosting the Development of the Blue Economy; Science Press: Beijing, China, 2020.

19. Engman, M. The Economic Impact of Trade Facilitation. Sourceoecd Emerg. Econ. 2009, 2009, 92-128.

20. Blonigen, B.A. A Review of the Empirical Literature on FDI Determinants. Atl. Econ. J. 2005, 33, 383-403. [CrossRef]

21. Furuichi, M. Cross-border logistics practices, policies, and its impact. In Global Logistics Network Modelling and Policy; Elsevier: Amsterdam, The Netherlands, 2021; pp. 47-69.

22. Dayal, R. Cross-border co-operation. Railw. Gaz. Int. 2019, 175, 23.

23. Lin, J.Y. "One Belt and One Road” and Free Trade Zones-China's New Opening-up Initiatives. Front. Econ. China 2015, 10, 585-590.

24. Wang, S.; Chen, S.; Zhang, H.; Song, M. The model of early warning for China's marine ecology-economy symbiosis security. Mar. Policy 2021, 128, 104476. [CrossRef]

25. The World Bank. Belt and Road Economics: Opportunities and Risks of Transport Corridors; The World Bank: Washington, DC, USA, 2019.

26. Pan, H. Research on International Logistics Supply Chain Management Mode from the Perspective of Cross-border E-commerce. In The International Conference on Cyber Security Intelligence and Analytics; Springer: Singapore, 2019; pp. 737-744.

27. Yang, J. Development and Innovation of the Belt and Road Cross-Border Logistics Service System. In Current Chinese Economic Report Series; Springer: Singapore, 2019; pp. 161-187.

28. Basalim, S. An Analysis of Cross-Border Freight Mode Choice Using Stereotype Logistic Regression: A Case Study. Int. J. Adv. Trends Comput. Sci. Eng. 2020, 9, 65-72. [CrossRef]

29. China Credit Insurance. Country Risk Analysis Report 2018-Country Risk Ratings, Sovereign Credit Risk Ratings and Risk Analysis of 62 Key Countries. 2018. Available online: http://www.sinosure.com.cn/gywm/gsjj/xxpl/xxgg/index.shtml (accessed on 29 October 2021).

30. National Information Center. "Belt and Road" Data Center, "Belt and Road" Trade Cooperation Data Report. 2018. Available online: http:/ / www.sinosure.com.cn/gywm/gsjj/xxpl/xxgg/index.shtml (accessed on 12 October 2020).

31. Cui, X.; Guo, L.; Li, F. Can trade facilitation promote inter-provincial trade through trade creation-Evidence from a study on trade facilitation in China. Financ. Trade Econ. 2019, 40, 100-115.

32. Zhang, Y. Investment facilitation and China's outward foreign direct investment choices under the "Belt and Road" - An empirical study based on cross-country panel data and investment attraction model. Int. Trade Issues 2016, 42, 165-176.

33. Sheng, B.; Jin, C. Analysis of trade facilitation levels in countries along the "Belt and Road" and China's countermeasures. Int. Trade 2019, 38, 4-13. 